\title{
Phenatic Acids A and B, New Potentiators of Antifungal Miconazole Activity Produced by Streptomyces sp. K03-0132
}

\author{
Takashi Fukuda, Atsuko Matsumoto, Yoko Takahashi, Hiroshi Tomoda, Satoshi Ōmura
}

Received: December 28, 2004 / Accepted: March 3, 2005

(C) Japan Antibiotics Research Association

\begin{abstract}
Two new phenols, designated phenatic acids $\mathrm{A}$ and $\mathrm{B}$, were isolated along with known actiphenol, from the culture of Streptomyces sp. K03-0132 by solvent extraction, silica gel column chromatography and HPLC. Their structures were elucidated by spectroscopic analyses including mainly various NMR experiments. They have a common 1-hydroxy 2, 4-dimethyl benzene ring. These compounds potentiate miconazole activity against Candida albicans. Phenatic acid B also showed moderate antimicrobial activity against Bacillus subtilis, Staphylococcus aureus, Bacteroides fragilis and Acholeplasma laidlawii.
\end{abstract}

Keywords phenatic acids, phenol, azole potentiator, actinomycetes, actiphenol

\section{Introduction}

Opportunistic infections caused by certain fungi, in particular the problematic Candida albicans, have increased recently and become a public concern [1]. Patients with compromised immune systems, e.g. patients receiving organ transplants and cancer chemotherapy, or those infected by human immunodeficiency virus (HIV), are particularly prone to such infections [1]. Azole derivatives, which inhibit fungal ergosterol biosynthesis by blockade of the cytochrome P-450 reaction involved in 14- $\alpha$ demethylation, are the most commonly used agents. In the last few years, several antifungal combination therapies have been evaluated against infections. However,

H. Tomoda (Corresponding author), T. Fukuda, A. Matsumoto, Y. Takahashi, S. Ōmura: Kitasato Institute for Life Sciences \& Graduate School of Infection Control Sciences, Kitasato new antifungal agents of a different mechanism of action have been sought extensively.

On the basis of the new concept "antiinfective drugs" [2], we discovered actofunicone [3] and beauvericins D, E and $F[4,5]$ from a fungal origin as potentiators of antifungal miconazole activity. The compounds showed no antimicrobial activity themselves, but reinforced miconazole activity against the growth of $C$. albicans. During the course of the continuous screening program, three 2,4-dimethyl phenols (Fig. 1) were isolated from the culture broth of strain Streptomyces sp. K03-0132. Two were found to be new compounds, designated phenatic acids $\mathrm{A}$ and $\mathrm{B}$, although one additional compound was identified as actiphenol which was previously isolated as an antifungal antibiotic and antitumor props produced by Streptomyces sp. [6, 7]. They all potentiated miconazole activity against $C$. albicans. In this paper, the taxonomy of the producing strain, fermentation, isolation, structure elucidation and biological properties of phenatic acids A and $\mathrm{B}$ are described.

\section{Materials and Methods}

\section{General Experimental Procedures}

The strain K03-0132 was isolated from soil collected at Mt. Daisetsu, Hokkaido, Japan and was used for production of phenatic acids A and B. C. albicans ATCC 64548 (KF-1, wild type) was purchased from ATCC (Virginia, USA). For determination of the amount of phenatic acids $\mathrm{A}$ and $\mathrm{B}$ in the culture broths, the samples were dissolved in methanol 
<smiles>Cc1cc(C)c(O)c(C(=O)CC(CC(N)=O)CC(=O)O)c1</smiles>

Phenatic acid A

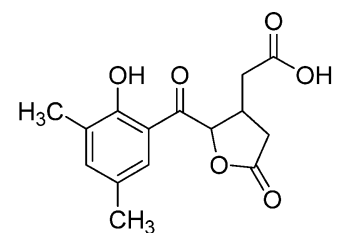

Phenatic acid B<smiles>Cc1cc(C)c(O)c(C(=O)CC2CC(=O)NC(=O)C2)c1</smiles>

Actiphenol<smiles>Cc1cc(C)c2c(c1)C(=O)C(C1CC(=O)NC(=O)C1)O2</smiles>

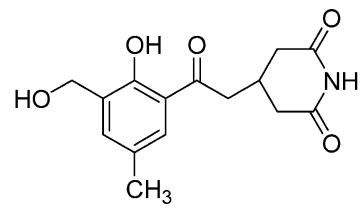

AH-135Y

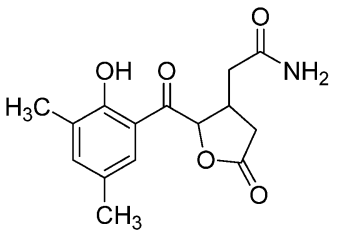

Nong-kang 101-F

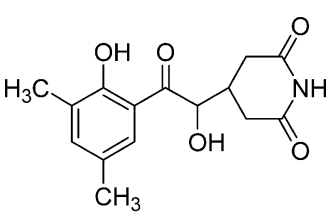

Nong-kang 101-G

Fig. 1 Structures of phenatic acids A and B and structurally related known compounds.

and analyzed with an HP 1100 system (Hewlett Packard Inc., Germany) under the following conditions: column, Symmetry $(2.1 \times 150 \mathrm{~mm}$, Waters Inc., Missouri, USA); flow rate, $0.2 \mathrm{ml} /$ minute; mobile phase, a 20 -minute linear gradient from $60 \% \quad \mathrm{CH}_{3} \mathrm{CN} / 0.05 \% \quad \mathrm{H}_{3} \mathrm{PO}_{4}$ to $100 \%$ $\mathrm{CH}_{3} \mathrm{CN} / 0.05 \% \mathrm{H}_{3} \mathrm{PO}_{4}$; detection, UV at $210 \mathrm{~nm}$. Phenatic acids $\mathrm{A}$ and $\mathrm{B}$ were eluted with retention times of 6.0 and 11.7 minutes, respectively.

Optical rotations were recorded with a DIP-370 digital polarimeter (JASCO, Tokyo, Japan). Melting points were measured with a micro melting apparatus (Yanaco, Kyoto, Japan). FAB-MS spectrometry was conducted on a JMSAX505H spectrometer (JEOL, Tokyo, Japan). UV and IR spectra were measured with a DU640 spectrophotometer (Beckman, California, USA) and an FT-210 Fourier transform infrared spectrometer (Horiba, Kyoto, Japan), respectively. The various NMR spectra were measured with an XL-400 spectrometer (Varian, California, USA).

\section{Taxonomic Studies}

The International Streptomyces Project (ISP) media recommended by Shirling and Gottlieb [7] and media recommended by Waksman [8] were used to investigate the cultural and physiological characteristics. Cultures were routinely observed after the incubation for two weeks at $27^{\circ} \mathrm{C}$. Color names and hue numbers were determined according to the Color Harmony Manual [9]. The utilization of carbon sources was tested by growth on Pridham and Gottlieb's medium containing 1\% carbon at $27^{\circ} \mathrm{C}$ [10]. The morphological properties were observed with a scanning electron microscope (model JSM-5600, JEOL). The type of diaminopimelic acid (DAP) isomers was determined by the method of Becker et al. [11]. Menaquinones were extracted and purified by the methods of Collins et al. [12], then analyzed by HPLC equipped with a CAPCELL PAK C18 column (Shiseido) [13].

\section{Assay for Miconazole-potentiating Activity}

C. albicans KF-1 (wild strain) was inoculated into a 50-ml test tube containing $10 \mathrm{ml}$ of seed medium (potato extract containing peptone $0.5 \%$ and glucose $1 \%$ ), and were grown for 24 hours on a rotary shaker at $210 \mathrm{rpm}$. The seed culture of C. albicans $(0.1 \%, \mathrm{v} / \mathrm{v})$ was transferred to the two different agar plates, GY agar (glucose $1 \%$, yeast extract $0.5 \%$ and agar $0.8 \%$ ) (Plate A) and GY agar plus miconazole $(0.06 \mu \mathrm{M})$ (Plate B). The concentration $(0.06 \mu \mathrm{M})$ of miconazole is one fourth of the MIC value against $C$. albicans, showed no effect on the growth of $C$. albicans. Paper disks ( $8 \mathrm{~mm}$, ADVANTEC, Tokyo, Japan) containing $10 \sim 50 \mu \mathrm{g}$ of a sample were put on Plates A and $\mathrm{B}$, which were incubated at $27^{\circ} \mathrm{C}$ for 24 hours. Samples showing inhibition zones selectively on Plate B were selected as potentiators of miconazole activity against $C$. albicans.

\section{Antimicrobial Activity}

Antimicrobial activity against 14 species of microorganisms was measured. The microorganisms were as follows; Bacillus subtilis PCI 219, Staphylococcus aureus FDA 209P, Micrococcus luteus PCI 1001, Mycobacterium smegmatis ATCC 607, Escherichia coli NIHJ, Pseudomonas aeruginosa P-3, Xanthomonas campestris pv. Oryzae KB 88, Bacteroides fragilis ATCC 23745, Acholeplasma laidlawii PG 8, Pyricularia oryzae KF 180, Aspergillus niger ATCC 6275, Mucor racemosus IFO 4581, C. albicans ATCC 64548 and Saccharomyces cerevisiae. Media for microorganisms were as follows: GAM agar (Nissui Seiyaku Co.) for B. fragilis; Bacto PPLO agar (Difco) supplemented with $15 \%$ horse serum, $0.1 \%$ glucose, $0.25 \%$ phenol red $(5 \mathrm{mg} / \mathrm{ml})$ and $1.5 \%$ agar for $A$. 
laidlawii; Taiyo agar (Shimizu Syokuhin Kaisya Ltd.) for the other bacteria; a medium composed of $1.0 \%$ yeast extract, and $0.8 \%$ agar for fungi and yeasts. A paper disk (i.d. $6 \mathrm{~mm}$, ADVANTEC) containing $10 \mu \mathrm{g}$ of a sample was placed on an agar plate. Bacteria except $X$. oryzae were incubated at $37^{\circ} \mathrm{C}$ for 24 hours. Yeasts and $X$. oryzae were incubated at $27^{\circ} \mathrm{C}$ for 24 hours. Fungi were incubated at $27^{\circ} \mathrm{C}$ for 48 hours. Antimicrobial activity was expressed as diameter $(\mathrm{mm})$ of the inhibitory zone.

\section{Results}

\section{Taxonomy of the Producing Strain K03-0132}

The vegetative mycelia grew abundantly on yeast extractmalt extract agar and others, and did not show fragmentation into coccoid forms or bacillary elements. The aerial mycelia grew abundantly on yeast extract - malt extract and others. The spore chains were spirals and each had more than 20 spores per chain. The spores were cylindrical in shape, $0.7 \times 1.2 \mu \mathrm{m}$ in size and had a smooth surface (Fig. 2). Whirls, sclerotic granules, sporangia and flagellate spores were not observed.

The isomer of DAP in whole-cell hydrolysates of strain K03-0132 was determined to be LL-form. Major menaquinones were MK-9 $\left(\mathrm{H}_{6}\right)$ and MK-9 $\left(\mathrm{H}_{8}\right)$.

The cultural characteristics, the physiological properties and the utilization of carbon sources are shown in Tables 1, 2 and 3. The color of vegetative mycelia showed yellow to brown and the aerial mass color showed brown to gray. Melanoid pigment was produced on tyrosine agar.

Based on the taxonomic properties described above, strain K03-0132 was considered to belong to the genus Streptomyces [14].

\section{Fermentation}

A slant culture of the strain K03-0132 grown on Seino agar (starch $1.0 \%, \mathrm{~N}-\mathrm{Z}$ amine $0.3 \%$, yeast extract $0.1 \%$, meat extract $0.1 \%, \mathrm{CaCO}_{3} 0.3 \%$, agar $1.0 \%, \mathrm{pH} 7.0$ ) was used to inoculate a $500-\mathrm{ml}$ Erlenmeyer flask containing $100 \mathrm{ml}$ of the seed medium (glucose $0.1 \%$, starch $2.4 \%$, peptone $0.3 \%$, meat extract $0.3 \%$, yeast extract $0.5 \%, \mathrm{CaCO}_{3} 0.4 \%$, $\mathrm{pH}$ 7.0). The flask was shaken on a reciprocal shaker for 4 days at $27^{\circ} \mathrm{C}$. One $\mathrm{ml}$ of the seed culture was incubated into a 500-ml Erlenmeyer flask containing $100 \mathrm{ml}$ of the production medium (starch $2.4 \%$, glucose $0.1 \%$, peptone $0.3 \%$, meat extract $0.3 \%$, yeast extract $0.5 \%, \mathrm{CaCO}_{3} 0.4 \%$, trace metals $5 \mathrm{ml} /$ liter, pH7.0). The fermentation was carried out at $27^{\circ} \mathrm{C}$ for 6 days.

A typical time course of the fermentation is shown in Fig. 3. Phenatic acids A and B were detected in the culture

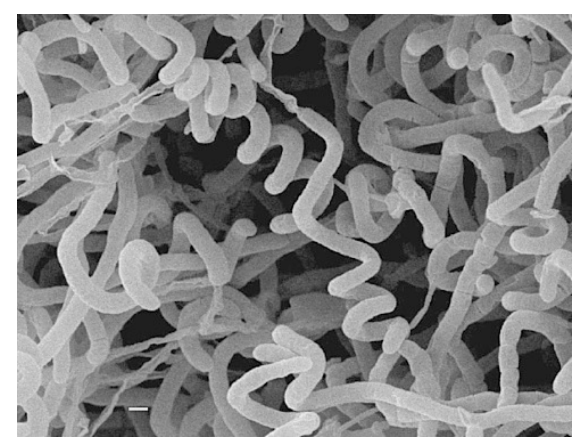

Fig. 2 Scanning electron micrograph of Streptomyces sp. K03-0132 grown on yeast extract - malt extract agar at $27^{\circ} \mathrm{C}$ for 14 days. Bar represents $1 \mu \mathrm{m}$.

broth from day 2 after inoculation. The concentration of phenatic acids A and B on day 6 reached levels of 6.7 and $19.7 \mu \mathrm{g} / \mathrm{ml}$, respectively.

\section{Isolation}

To the 6-day old culture broth (1 liter) was added 1 liter of ethanol. After the ethanol extracts were filtered and concentrated, the resulting aqueous solution was extracted with 1 liter of ethyl acetate. The ethyl acetate layer was dried over $\mathrm{Na}_{2} \mathrm{SO}_{4}$ and concentrated in vacuo to dryness to yield an oily material $(362.1 \mathrm{mg})$. The material was dissolved in a small volume of $\mathrm{CHCl}_{3}$, applied on a silica gel column ( $20 \mathrm{~g}, 2.5 \times 12 \mathrm{~cm}, 70 \sim 230 \mathrm{mesh}$, Merck), and eluted stepwise with $100 \% \mathrm{CHCl}_{3}, 100: 1,50: 1,10: 1$, $5: 1$ and $1: 1(\mathrm{v} / \mathrm{v})$ of $\mathrm{CHCl}_{3}-\mathrm{CH}_{3} \mathrm{OH}$ solvents and $100 \%$ $\mathrm{MeOH}(200 \mathrm{ml}$ each). The antimicrobial activity against $S$. aureus was observed in the three fractions 100:1 (I), $5: 1$ (II) and $1: 1$ (III) which were concentrated to give a white powder I (37.4 mg), brown material II $(41.0 \mathrm{mg})$ and brown material III ( $40.7 \mathrm{mg}$ ), respectively. The white powder I was recrystallized from $\mathrm{MeOH}$ to give actiphenol $(5.5 \mathrm{mg})$ as white needles. The brown material III was purified by HPLC; ODS column $(4.6 \times 250 \mathrm{~mm}$, Pegasil, Senshu Sci. Co. Tokyo, Japan), a 30-minute linear gradient from 10 to $50 \% \mathrm{CH}_{3} \mathrm{CN}$ in $0.05 \%$ TFA, $1.0 \mathrm{ml} /$ minute, and $\mathrm{UV}$ at $210 \mathrm{~nm}$. Under the conditions, phenatic acid A was eluted as a peak with a retention time of 20 minutes. The fraction was concentrated to yield pure phenatic acid A $(4.0 \mathrm{mg})$ as colorless needles. The brown material II was purified by HPLC under the same conditions. Phenatic acid B was eluted as a peak with a retention time of 28 minutes to give pure phenatic acid B $(4.0 \mathrm{mg})$ as colorless needles.

\section{Structure Elucidation}

\section{Physico-chemical Properties of Phenatic Acids}

Physico-chemical properties of phenatic acids are summarized in Table 4. Similarity in their data indicated 
Table 1 Cultural characteristics of strain K03-0132

\begin{tabular}{|c|c|c|c|}
\hline Medium & Cultural characteristics & Medium & Cultural characteristics \\
\hline $\begin{array}{l}\text { Yeast extract-malt } \\
\text { extract agar }{ }^{\text {a }}\end{array}$ & $\begin{array}{l}\text { G: Good, yellow maple (3ng) } \\
\text { R: Clove brown (3pl) } \\
\text { AM: Abundant, dark covert gray (2ih) } \\
\text { SP: Trace, golden brown (3pg) }\end{array}$ & Tyrosine agar ${ }^{a}$ & $\begin{array}{l}\text { G: Good, light mustard tan (2ie) } \\
\text { R: Mustard tan (2lg) } \\
\text { AM: Moderate, silver gray (3fe) } \\
\text { SP: Trace, light mustard tan (2ie) }\end{array}$ \\
\hline Oatmeal agar ${ }^{a}$ & $\begin{array}{l}\text { G: Good, mustard (2le) } \\
\text { R: Dark covert gray (2ih) } \\
\text { AM: Moderate, beige brown (3ig) } \\
\text { SP: None }\end{array}$ & Sucrose - nitrate agar ${ }^{b}$ & $\begin{array}{l}\text { G: Good, pearl }(2 \mathrm{ba}) \\
\text { R: Silver gray }(3 \mathrm{fe}) \\
\text { AM: Poor, beige }(3 \mathrm{ge}) \\
\text { SP: None }\end{array}$ \\
\hline $\begin{array}{l}\text { Inorganic salts - starch } \\
\text { agar }^{\text {a }}\end{array}$ & $\begin{array}{l}\text { G: Good, mustard (2le) } \\
\text { R: Light mustard tan (2ie) } \\
\text { AM: Abundant, covert gray (2fe) } \\
\text { SP: Trace, light mustard tan (2ie) }\end{array}$ & Glucose-nitrate agar ${ }^{b}$ & $\begin{array}{l}\text { G: Moderate, pearl ( } 2 \mathrm{ba}) \\
\text { R: Pearl (2ba) } \\
\text { AM: Poor, beige }(3 \mathrm{ge}) \\
\text { SP: None }\end{array}$ \\
\hline $\begin{array}{l}\text { Glycerol-asparagine } \\
\text { agar }^{\text {a }}\end{array}$ & $\begin{array}{l}\text { G: Good, camel (3ie) } \\
\text { R: Adoobe brown (3lg) } \\
\text { AM: Abundant, beige gray (3ih) } \\
\text { SP: Trace, mustard }\end{array}$ & $\begin{array}{l}\text { Glycerol - calcium } \\
\text { malate agar }{ }^{\text {b }}\end{array}$ & $\begin{array}{l}\text { G: Good, pearl pink (3ca) } \\
\text { R: Pearl pink (3ca) } \\
\text { AM: None } \\
\text { SP: None }\end{array}$ \\
\hline $\begin{array}{l}\text { Glucose - asparagine } \\
\text { agar }\end{array}$ & $\begin{array}{l}\text { G: Moderate, pearl (2ba) } \\
\text { R: Pearl (2ba) } \\
\text { AM: None } \\
\text { SP: None }\end{array}$ & Glucose - peptone agar ${ }^{\text {b }}$ & $\begin{array}{l}\text { G: Good, ivory (2db) } \\
\text { R: Mustard (2le) } \\
\text { AM: None } \\
\text { SP: None }\end{array}$ \\
\hline $\begin{array}{l}\text { Peptone - yeast } \\
\text { extract - iron agar }{ }^{\text {a }}\end{array}$ & $\begin{array}{l}\text { G: Good, bamboo }(2 \mathrm{gc}) \\
\text { R: Honey gold (2ic) } \\
\text { AM: None } \\
\text { SP: Trace, honey gold (2ic) }\end{array}$ & Nutrient agar ${ }^{b}$ & $\begin{array}{l}\text { G: Good, cream (11/2ca) } \\
\text { R: Cream (11/2ca) } \\
\text { AM: Poor, natural (2dc) } \\
\text { SP: None }\end{array}$ \\
\hline
\end{tabular}

a; Medium recommended by ISP, b; Medium recommended by S. A. Waksman.

Abbreviations: G, growth of vegetative mycelium; R, reverse side color; AM, aerial mycelium; SP, soluble pigment.

Table 2 Physiological properties of strain K03-0132

$\begin{array}{ll}\text { Melanin formation } & \\ \text { Tyrosine agar } & \text { positive } \\ \text { Peptone - yeast extract - iron agar } & \text { negative } \\ \text { Tryptone - yeast extract broth } & \text { negative } \\ \text { Gelatin medium } & \text { negative } \\ \text { Reduction of nitrate } & \text { positive } \\ \text { Liquefaction of gelatin }\left(21 \sim 23^{\circ} \mathrm{C}\right) & \text { positive } \\ \text { Hydrolysis of starch } & \text { positive } \\ \text { Coagulation of milk }\left(37^{\circ} \mathrm{C}\right) & \text { negative } \\ \text { Peptonization of milk }\left(37^{\circ} \mathrm{C}\right) & \text { negative } \\ \text { Decomposition of cellulose } & \text { negative } \\ \text { Temperature range for growth } & 7 \sim 38^{\circ} \mathrm{C}\end{array}$

that they are structurally related. IR spectrum of phenatic acid A showed absorptions at 3440, 3212, 3137, 1712, 1660 and $1633 \mathrm{~cm}^{-1}$, suggesting the presence of an amide carbonyl, a carboxylic acid and a carbonyl residue. That of
Table 3 Utilization of carbon sources by strain K03-0132

$\begin{array}{ll}\text { Utilized: } & \text { D-Glucose, Melibiose, L-Rhamnose } \\ \text { Weakly utilized: } & \text { D-Fructose, Raffinose, Sucrose, D-Xylose } \\ \text { Not utilized: } & \text { L-Arabinose, myo-Inositol, D-Mannitol }\end{array}$

phenatic acid B showed absorptions at 3100, 3037, 1781, 1708 and $1637 \mathrm{~cm}^{-1}$, suggesting the presence of a carboxylic acid and two carbonyl residues.

\section{Phenatic Acid A}

The molecular formula of phenatic acid A was determined to be $\mathrm{C}_{15} \mathrm{H}_{19} \mathrm{NO}_{5}$ on the basis of HRFAB-MS measurement (Table 4). The ${ }^{13} \mathrm{C}$ NMR spectrum (in $\mathrm{CDCl}_{3}$ ) showed 15 resolved signals, which were classified into two methyl carbons, three methylene carbons, one methine carbon, three $s p^{2}$ methine carbons, four quaternary carbons and three carbonyl carbons by analysis of DEPT spectra. The 
${ }^{1} \mathrm{H}$ NMR spectrum (in $\mathrm{CDCl}_{3}$ ) showed two methyl signals, two methylene signals, one methine signal, two aromatic signals and two $\mathrm{N}-\mathrm{H}$ signals. The connectivity of proton and carbon atoms was established by the ${ }^{13} \mathrm{C}-{ }^{1} \mathrm{H}$ HMQC spectrum as shown in Table 5. Analysis of the ${ }^{1} \mathrm{H}-{ }^{1} \mathrm{H}$ COSY and ${ }^{13} \mathrm{C}-{ }^{1} \mathrm{H}$ HMBC spectra revealed the partial structure (Fig. 4).

The ${ }^{13} \mathrm{C}-{ }^{1} \mathrm{H}$ long range couplings of ${ }^{2} J$ and ${ }^{3} J$ observed in the ${ }^{13} \mathrm{C}-{ }^{1} \mathrm{H}$ HMBC experiments (Fig. 5) gave the following

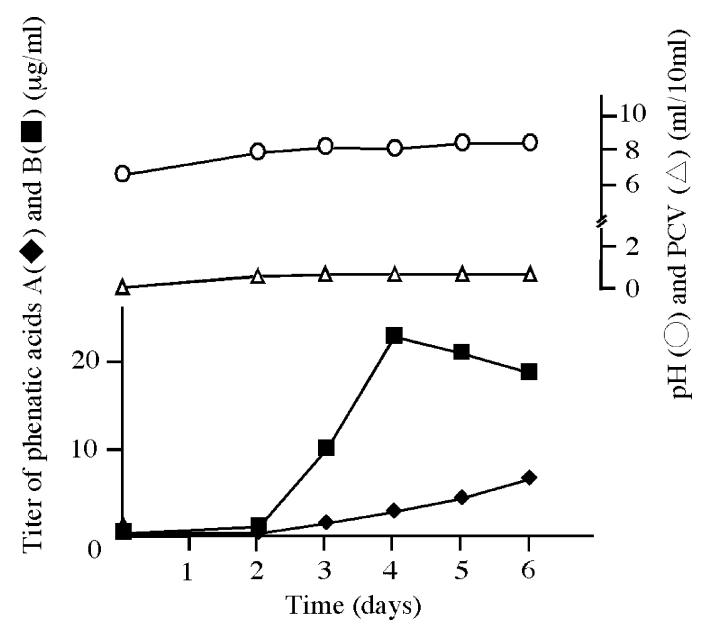

Fig. 3 A typical time course of production phenatic acids A and B by Streptomyces sp. K03-0132. The amounts of phenatic acids $A(\bullet)$ and $B(\square)$ in culture broths were determined by HPLC as described in Materials and Methods. PCV, packed cell volume $(\mathrm{ml})$ from $10 \mathrm{ml}$ of the whole culture broth after centrifugation at $3000 \mathrm{rpm}$. results. 1) The cross peaks from $3-\mathrm{H}(\delta 7.09)$ to $\mathrm{C}-1(\delta$ $159.0)$ and $\mathrm{C}-5(\delta 127.3)$, from $5-\mathrm{H}(\delta 7.43)$ to $\mathrm{C}-1$ and $\mathrm{C}-$ $3\left(\delta\right.$ 138.6), from $14-\mathrm{H}_{3}(\delta 2.14)$ to $\mathrm{C}-1, \mathrm{C}-2(\delta 127.2)$ and $\mathrm{C}-3$ and from $15-\mathrm{H}_{3}(\delta 2.20)$ to $\mathrm{C}-3, \mathrm{C}-4(\delta 127.5)$ and $\mathrm{C}-5$ supported the partial structure I. 2) The cross peaks from 8$\mathrm{H}_{2}(\delta$ 3.12) to $\mathrm{C}-6(\delta 118.5), \mathrm{C} 7(\delta 206.0), \mathrm{C}-9(\delta 29.2)$, $\mathrm{C}-10(\delta 38.1)$ and $\mathrm{C}-12(\delta 39.3)$, from $9-\mathrm{H}(\delta 2.86)$ to $\mathrm{C}-8$ $(\delta 42.0), \mathrm{C}-10, \mathrm{C}-11(\delta 174.2), \mathrm{C}-12$ and $\mathrm{C}-13(\delta$ 174.4), from $10-\mathrm{H}_{2}(\delta 2.45)$ to $\mathrm{C}-8, \mathrm{C}-9, \mathrm{C}-11$ and $\mathrm{C}-12$, from $12-$ $\mathrm{H} 2$ ( $\delta$ 2.32) to $\mathrm{C}-8, \mathrm{C}-9, \mathrm{C}-10$ and $\mathrm{C}-13$ supported the partial structure II. 3) The cross peaks from $5-\mathrm{H}$ to $\mathrm{C}-7$ and $8-\mathrm{H}_{2}$ to $\mathrm{C} 7$ showed that the partial structure $\mathrm{I}$ is linked to the partial structure II. 4) From the data of IR, the chemical sifts and molecular formula, C-11 should be the carboxylic acid carbon and $\mathrm{C}-13$ is the amino carbonyl carbon.

Taken together, the structure of phenatic acid A was elucidated as shown in Fig 1. All the data assigned here is very reasonable in comparison with those of actiphenol reported previously [6].

\section{Phenatic Acid B}

The molecular formula $\left(\mathrm{C}_{15} \mathrm{H}_{16} \mathrm{O}_{6}\right)$ of phenatic acid $\mathrm{B}$ is $\mathrm{NH}_{3}$ smaller and $\mathrm{O}$ bigger than that of phenatic acid $\mathrm{A}$. The difference between phenatic acids $\mathrm{A}$ and $\mathrm{B}$ is due to the partial structure III for phenatic acid B, which was elucidated by the ${ }^{1} \mathrm{H}-{ }^{1} \mathrm{H}$ COSY and ${ }^{13} \mathrm{C}-{ }^{1} \mathrm{H}$ HMBC experiments (Fig. 6), in place of the partial structure II for phenatic acid A. The cross peaks from $8-\mathrm{H}(\delta 5.70)$ to $\mathrm{C}-7$ $(\delta 198.5), \mathrm{C}-9(\delta 34.7), \mathrm{C}-10(\delta 37.0)$ and $\mathrm{C}-13(\delta 175.0)$, from $10-\mathrm{H}_{2}(\delta 2.52,2.65)$ to $\mathrm{C}-8(\delta 80.7), \mathrm{C}-9, \mathrm{C}-11$

Table 4 Physico-chemical properties of phenatic acids A and B

\begin{tabular}{|c|c|c|}
\hline & Phenatic acid $\mathrm{A}$ & Phenatic acid B \\
\hline Appearance & White needle & White needle \\
\hline Melting point & $147 \sim 149^{\circ} \mathrm{C}$ & $196 \sim 197^{\circ} \mathrm{C}$ \\
\hline$[\alpha]_{D}^{26}$ & $+2.5\left(\mathrm{c} 0.1, \mathrm{CH}_{3} \mathrm{OH}\right)$ & $-2.2\left(\mathrm{c} 0.1, \mathrm{CH}_{3} \mathrm{OH}\right)$ \\
\hline Molecular formula & $\mathrm{C}_{15} \mathrm{H}_{19} \mathrm{NO}_{5}$ & $\mathrm{C}_{15} \mathrm{H}_{16} \mathrm{O}_{6}$ \\
\hline Molecular weight & 293 & 292 \\
\hline \multicolumn{3}{|l|}{ HR-FAB-MS m/z } \\
\hline Calcd & $294.1341(\mathrm{M}+\mathrm{H})^{+}$ & $292.0946(\mathrm{M})^{+}$ \\
\hline Found & 294.1335 & 292.0948 \\
\hline$U V \lambda_{\max }^{\mathrm{CH}_{3} \mathrm{OH}} \mathrm{nm}(\varepsilon)$ & $\begin{array}{l}217(12,500), 262(6,700) \\
345(2,300)\end{array}$ & $\begin{array}{l}217(8,900), 267(6,100), \\
355(1,900)\end{array}$ \\
\hline $\mathrm{IR} v_{\max }^{\mathrm{KBr}} \mathrm{cm}^{-1}$ & $\begin{array}{l}3440,3212,3137,1712 \\
1660,1633\end{array}$ & $\begin{array}{l}3100,3037,1781,1708 \\
1637\end{array}$ \\
\hline \multicolumn{3}{|l|}{ Solubility } \\
\hline Soluble & $\begin{array}{l}\mathrm{DMSO}, \mathrm{CH}_{3} \mathrm{OH} \\
\mathrm{CHCl}_{3}, \text { ethyl acetate }\end{array}$ & $\begin{array}{l}\text { DMSO, } \mathrm{CH}_{3} \mathrm{OH} \\
\mathrm{CHCl}_{3} \text {, ethyl acetate }\end{array}$ \\
\hline Insoluble & $n$-Hexane, $\mathrm{H}_{2} \mathrm{O}$ & $n$-Hexane, $\mathrm{H}_{2} \mathrm{O}$ \\
\hline
\end{tabular}


Table $5 \quad{ }^{1} \mathrm{H}$ and ${ }^{13} \mathrm{C}$ NMR chemical shifts of phenatic acids $\mathrm{A}$ and $\mathrm{B}$

\begin{tabular}{|c|c|c|c|c|}
\hline & \multicolumn{2}{|c|}{ Phenatic acid $A$} & \multicolumn{2}{|r|}{ Phenatic acid B } \\
\hline & $\begin{array}{l}{ }^{13} \mathrm{C} \text { chemical } \\
\text { shifts (ppm) })^{a}\end{array}$ & $\begin{array}{l}{ }^{1} \mathrm{H} \text { chemical } \\
\text { shifts }(p p m)^{\mathrm{b}}\end{array}$ & $\begin{array}{l}{ }^{13} \mathrm{C} \text { chemical } \\
\text { shifts (ppm) }{ }^{\mathrm{a}}\end{array}$ & $\begin{array}{l}{ }^{1} \mathrm{H} \text { chemical } \\
\text { shifts }(\mathrm{ppm})^{\mathrm{b}}\end{array}$ \\
\hline C-1 & 159.0 & & 159.9 & \\
\hline $\mathrm{C}-2$ & 127.2 & & 128.0 & \\
\hline C-3 & 138.6 & $7.09(1 \mathrm{H}$, br.s $)$ & 139.8 & $7.20(1 \mathrm{H}$, br.s $)$ \\
\hline C-4 & 127.5 & & 129.0 & \\
\hline C-5 & 127.3 & $7.43(1 \mathrm{H}$, br.s $)$ & 126.9 & $7.52(1 \mathrm{H}$, br.s $)$ \\
\hline C-6 & 118.5 & & 114.0 & \\
\hline C-7 & 206.0 & & 198.5 & \\
\hline C-8 & 42.0 & $3.12(2 \mathrm{H}, \mathrm{d}, J=6.5 \mathrm{~Hz})$ & 80.7 & $5.70(1 \mathrm{H}, \mathrm{d}, J=3.0 \mathrm{~Hz})$ \\
\hline C-9 & 29.2 & $2.86(1 \mathrm{H}, \mathrm{ddd}, J=6.7,6.7,6.5 \mathrm{~Hz})$ & 34.7 & $3.07(1 \mathrm{H}, \mathrm{m})$ \\
\hline C-10 & 38.1 & $2.45(2 \mathrm{H}, \mathrm{d}, J=6.7 \mathrm{~Hz})$ & 37.0 & $\begin{array}{l}2.52(1 \mathrm{H}, \mathrm{dd}, J=7.0,17.0 \mathrm{~Hz} \\
2.65(1 \mathrm{H}, \mathrm{dd}, J=8.0,17.0 \mathrm{~Hz}\end{array}$ \\
\hline C-11 & 174.2 & & 172.2 & \\
\hline $\mathrm{C}-12$ & 39.3 & $2.32(2 \mathrm{H}, \mathrm{d}, J=6.7 \mathrm{~Hz})$ & 39.0 & $\begin{array}{l}2.31(2 \mathrm{H}, \mathrm{dd}, J=3.5,17.5 \mathrm{~Hz}) \\
2.82(2 \mathrm{H}, \mathrm{dd}, J=8.5,17.5 \mathrm{~Hz}\end{array}$ \\
\hline $\mathrm{C}-13$ & 174.4 & & 175.0 & \\
\hline C-14 & 15.3 & $2.14(3 \mathrm{H}, \mathrm{s})$ & 15.4 & $2.19(3 \mathrm{H}, \mathrm{s})$ \\
\hline C-15 & 20.4 & $2.20(3 \mathrm{H}, \mathrm{s})$ & 20.4 & $2.25(3 \mathrm{H}, \mathrm{s})$ \\
\hline $\mathrm{NH}$ & & $5.64,6.39(2 \mathrm{H}$, br. s) & & \\
\hline $\mathrm{OH}$ & & $12.30(1 \mathrm{H}, \mathrm{s})$ & & $11.80(1 \mathrm{H}, \mathrm{s})$ \\
\hline
\end{tabular}

a) Chemical shifts are shown with reference to $\mathrm{CDCl}_{3}$ as $77.0 \mathrm{ppm}$. b) Chemical shifts are shown with reference to $\mathrm{CDCl}{ }_{3}$ as $7.26 \mathrm{ppm}$.

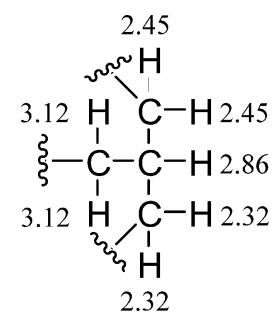

Fig. 4 Partial structure of phenatic acid A.

$\left(\delta\right.$ 172.2) and $\mathrm{C}-12(\delta 33.0)$, and from $12-\mathrm{H}_{2}(\delta 2.31,2.82)$ to $\mathrm{C}-9, \mathrm{C}-10$ and $\mathrm{C}-13$ were observed in the ${ }^{13} \mathrm{C}-{ }^{1} \mathrm{H}$ HMBC experiments to give the partial structure III. The cross peaks from $5-\mathrm{H}(\delta 7.52)$ to $\mathrm{C}-7$ and from $8-\mathrm{H}$ to $\mathrm{C}-7$ indicated that the partial structures I and III are connected to give the structure for phenatic acid B as shown in Fig. 1. The molecular formula supported the structure.

\section{Biological Properties}

\section{Miconazole-potentiating Activity}

The miconazole-potentiating activity of three phenatic acids and actiphenol was tested. All the compounds themselves showed no inhibition against $C$. albicans at
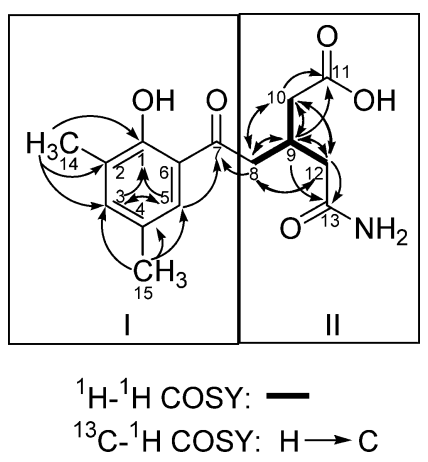

Fig. $5{ }^{1} \mathrm{H}-{ }^{1} \mathrm{H}$ COSY and ${ }^{13} \mathrm{C}-{ }^{1} \mathrm{H}$ HMBC experiments of phenatic acid $A$.

$50 \mu \mathrm{g} /$ disk on Plate A. Phenatic acid B showed dozedependent inhibition against the growth of $C$. albicans on Plate B. Phenatic acid A and actiphenol inhibited the growth on Plate B (12 and $16 \mathrm{~mm}$ inhibition zone, respectively) at $50 \mu \mathrm{g} /$ disk (Table 6). These results indicated that phenatic acids $\mathrm{A}$ and $\mathrm{B}$ and actiphenol potentiate the antifungal activity of miconazole against C. albicans strain KF-1. However, under the similar 


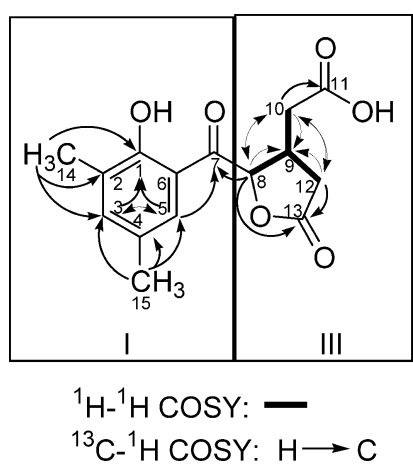

Fig. $6{ }^{1} \mathrm{H}^{-1} \mathrm{H}$ COSY and ${ }^{13} \mathrm{C}^{-1} \mathrm{H}$ HMBC experiments of phenatic acid $\mathrm{B}$.

conditions, no potentiation of miconazole activity by these compounds was observed against Aspergillus niger and Mucor racemosus.

\section{Antimicrobial Activities}

Phenatic acid B showed weak antibacterial activity against B. subtilis (inhibition zone at a concentration $10 \mu \mathrm{g} / 6 \mathrm{~mm}$ disk: $10 \mathrm{~mm})$ S. aureus $(8 \mathrm{~mm})$, B. fragilis $(13 \mathrm{~mm})$ and A. laidlawii $(12 \mathrm{~mm})$, but no activity against the other microorganisms: M. luteus, M. smegmatis, E. coli, P. aeruginosa, $X$. oryzae, $P$. oryzae, A. niger, M. racemosus, $C$. albicans and $S$. cerevisiae. Phenatic acid A and actiphenol did not show antimicrobial activity against the microorganisms at $10 \mu \mathrm{g} /$ disk (Table 7).

\section{Discussion}

As elucidated in this paper, phenatic acids A and B are new compounds belonging to 2,4-dimethyl phenol family. Structurally related known compounds (Fig. 1) show a variety of biological activities. For example, actiketal was reported as a weak inhibitor of mitogenic activity [15]. AH$135 \mathrm{Y}$ was reported to show the antiherpetic activity [16]. Actiphenol showed herbicidal, antifungal and antitumor activities $[6,7]$. As described in this paper, phenatic acids $\mathrm{A}$ and $\mathrm{B}$ and actiphenol were found to show moderate miconazole potentiating activity (Table 6 ).

The three compounds described above have a common glutarimide ring at the side chain. Whereas, the glutarimide ring was opened for phenatic acid $\mathrm{A}$, and further recyclized to form a $\gamma$-lactone ring at C-8 for phenatic acid B. Nongkang $101 \mathrm{~F}$ and $101 \mathrm{G}$, previously reported as antifungal antibiotics [17], showed very similar structures to phenatic acids $\mathrm{A}$ and $\mathrm{B}$, respectively. Unfortunately nong-kangs have not been isolated so far from the culture broth of the
Table 6 Effect of phenols on miconazole activity against Candida albicans (KF-1)

\begin{tabular}{|c|c|c|c|}
\hline \multirow{2}{*}{ Compound } & \multirow{2}{*}{$\begin{array}{c}\text { Concentration } \\
\mu \mu \mathrm{g} / \text { disk }\end{array}$} & \multicolumn{2}{|c|}{ Inhibition zone (mm) } \\
\hline & & Plate A & Plate B \\
\hline \multirow[t]{3}{*}{ Phenatic acid A } & 10 & - & - \\
\hline & 25 & - & - \\
\hline & 50 & - & 12 \\
\hline \multirow[t]{3}{*}{ Phenatic acid B } & 10 & - & - \\
\hline & 25 & - & 11 \\
\hline & 50 & - & 14 \\
\hline \multirow[t]{3}{*}{ Actiphenol } & 10 & - & - \\
\hline & 25 & - & - \\
\hline & 50 & - & 16 \\
\hline
\end{tabular}

Paper disks ( $8 \mathrm{~mm}$ i.d.) containing three concentrations of a compound were put on Plate A (C. albicans in GY agar) and Plate B (C. albicans in $\mathrm{GY}$ agar $+0.06 \mu \mathrm{M}$ miconazole), and incubated at $27^{\circ} \mathrm{C}$. After 24 hours, the diameters of inhibition zones were measured.

The concentration $(0.06 \mu \mathrm{M})$ of miconazole is one fourth of the MIC value against $C$. albicans showed no effect on the growth of $C$. albicans.

phenatic acid producing strain. Taking the presence/ absence of a hydroxy group at C-8 into consideration, phenatic acid $\mathrm{A}$ and actiphenol are structurally related, and phenatic acid B and nong-kangs are also related. Regarding the miconazole-potentiating activity (Table 6), the common 1-hydroxy 2,4-dimethyl aromatic ring is essential for exhibiting the activity. Furthermore, cyclic side chains such as glutarimide and $\gamma$-lactone rings appear to exhibit stronger activity than the linear side chains.

Acknowledgment We wish to thank Ms. Noriko Sato, Ms. Akiko Nakagawa and Ms. Chikako Sakabe, School of Pharmaceutical Sciences, Kitasato University, for measurements of NMR and mass spectra. This study was supported by the $21 \mathrm{st}$ Century COE Program and KAKENHI 16073215, Ministry of Education, Culture, Sports, Science and Technology, Japan.

\section{References}

1. Nishiyama Y, Yamaguchi H. Mode of action of antifungal agents for treatment of systematic fungal infection. Antibiot Chemother 16: 19-26 (2000)

2. Ōmura S. Antiinfective drugs into the 21 st century. Nippon Saikingaku Zasshi 54: 795-813 (1999)

3. Arai M, Tomoda H, Okuda H, Wang H, Tabata N, Masuma R, Yamaguchi Y, Ōmura S. Funicone-related compounds, potentiators of antifungal miconazole activity, prodused by Talaromyces flavus FKI-0067. J Antibiot 55: 172-180 
Table 7 Effect of phenols against microorganisms

\begin{tabular}{|c|c|c|c|}
\hline \multirow{2}{*}{ Microorganism } & \multicolumn{3}{|c|}{ Inhibition zone (mm) } \\
\hline & Phenatic acid $A$ & Phenatic acid B & Actiphenol \\
\hline Bacillus subtilis PCI 219 & - & 10 & - \\
\hline Staphylococcus aureus FDA 209 P & - & 8 & - \\
\hline Micrococcus luteus PCI 1001 & - & - & - \\
\hline Mycobacterium smegmatis ATCC 607 & - & - & - \\
\hline Eschrichia coli NIHJ & - & - & - \\
\hline Pseudomonas aeruginosa P-3 & - & - & - \\
\hline Xanthomonas oryzae KB 88 & - & - & - \\
\hline Bacteroides fragilis ATCC 23745 & - & 13 & - \\
\hline Acholeplasma laidlawii PG 8 & - & 12 & - \\
\hline Pyricularia oryzae KF 180 & - & - & - \\
\hline Aspergillus niger ATCC 6275 & - & - & - \\
\hline Mucor racemosus IFO 4581 & - & - & - \\
\hline Candida albicans ATCC 64548 & - & - & - \\
\hline Saccharomyces cerevisiae & - & - & - \\
\hline
\end{tabular}

Paper disks (6 mm i.d.) containing $10 \mu \mathrm{g}$ of compound were put on plate, and incubated at $27^{\circ} \mathrm{C}$ or $37^{\circ} \mathrm{C}$. After 24 or 48 hours, the diameters of inhibition zones were measured.

(2002)

4. Fukuda T, Tomoda H, Arai M, Ōmura S. New beauvericins, potentiators of antifungal miconazole activity, produced by Beauveria sp. FKI-1366. I. Taxonomy, fermentation, isolation and biological properties. J Antibiot 57: 110-116 (2004)

5. Fukuda T, Tomoda H, Arai M, Ōmura S. New beauvericins, potentiators of antifungal miconazole activity, produced by Beauveria sp. FKI-1366. II. Structure elucidation. J Antibiot 57: 117-124 (2004)

6. Highet RJ, Prelog J. Sttoffwechselprodukte von Actinomyceten, Actiphenol. Helv Chim Acta 42: 1523-1526 (1956)

7. Shirling EB, Gottlieb D. Methods for characterization of Streptomyces species. Int J Syst Bacteriol 16: 313-340 (1966)

8. Waksman SA (ed.). The Actinomycetes, Vol.2. Williams \& Wilkins, Baltimore (1961)

9. Color Harmony Manual, 4th. ed. Container Corporation of America, Chicago (1958)

10. Pridham TG, Gottlieb D. The utilization of carbon compounds by some Actinomycetales as an aid for species determination. J Bacteriol 56: 107-114 (1948)

11. Becker B, Lechevalier MP, Lechevalier HA. Chemical composition of cell-wall preparation from strains of various form-genera of aerobic actinomycetes. Appl Microbiol 13(2): 236-243 (1965)

12. Colling MD, Goodfellow M, Minnikin DE. Distribution of menaquinones in actinomycetes and corynebacteria. J Gen Microbiol 100: 221-230 (1977)

13. Tamaoka J, Katayama FY, Kuranishi H. Analysis of bacterial menaquinone mixtures by high performance liquid chromatography. J Appl Bacteriol 54: 31-36 (1983)

14. Williams ST, Goodfellow M, Alderson G. Genus Streptomyces Waksman and Henrici 1943. In: Wiliams ST, et al. (ed.). Bergey's Manual of Systematic Bacteriology, Vol. 4. Williams \& Wilkins, Baltimore, pp. 2452-2492 (1989)

15. Sonoda T, Osada H, Uzawa J, Isono K. Actiketal, a new member of the glutarimide antibiotics. J Antibiot 44: $160-163$ (1991)

16. Uyeda M, Aoki M, Nakajima K, Shimamoto C, Tathuguchi N, Yokomizo K, Kido Y, Kino Y. A new antiherpetic agent, AH-135Y, produced by Streptomyces albovinaceus strain NO. AH135. J Antibiot 45: 1370-1072 (1992)

17. Hua JC, Xie YY. Isolation and structure of antibiotics nongkang 101-F and 101-G. Hua Hsueh Hsueh Pao 38: 275-282 (1980) 